ISSN (print): 1698-6180. ISSN (online): 1886-7995

www.ucm.es/info/estratig/journal.htm

Journal of Iberian Geology 39 (1) 2013: 181-195

http://dx.doi.org/10.5209/rev_JIGE.2013.v39.n1.41758

\title{
Application of four sets of tectonomagmatic discriminant function based diagrams to basic rocks from northwest Mexico
}

\author{
Aplicación de cuatro conjuntos de diagramas tectonomagmáticos basados \\ en funciones discriminantes a rocas básicas del noroeste de México
}

\author{
K. Pandarinath ${ }^{1 *}$, S. K. Verma ${ }^{2,3}$ \\ ${ }^{1}$ Departamento de Sistemas Energéticos, Instituto de Energías Renovables, Universidad Nacional Autónoma \\ de México, Privada Xochicalco s/no., Centro, Apartado Postal 34, Temixco, Mor., 62580, Mexico \\ ${ }^{2}$ Posgrado en Ingeniería, Instituto de Energías Renovables, Universidad Nacional Autónoma de \\ México, Privada Xochicalco s/no., Col. Centro, Apartado Postal 34, Temixco, Mor., 62580, Mexico \\ ${ }^{3}$ Present address: Department of Geology and Natural Resources, Institute of Geosciences, P.O. Box \\ 6152, University of Campinas-UNICAMP, 13083-970, Campinas, SP, Brazil \\ *corresponding author:pk@ier.unam.mx
}

Received: 02/05/2011 / Accepted: 12/04/2013

\begin{abstract}
Discrimination diagrams are being widely used for the past four decades to infer the tectonomagmatic affiliation of old rocks. There are several major- and trace-element composition based bivariate, ternary and multi-element discriminant function diagrams in the literature. Recent evaluation of the performance of these diagrams indicates that four sets of recent discriminant function based diagrams, in which the tectonic boundaries are determined from probability estimates for four tectonic settings of island arc, continental rift, ocean-island and mid-ocean ridge, have shown very high success rates. In this work, we have created an extensive geochemical database for on-land and off-shore basic rocks of northwest Mexico and applied these four sets of recent and highly successful tectonomagmatic discriminant function based diagrams to infer their tectonomagmatic origin. Each of these four sets of diagrams (two for major- and two for trace-elements) contained five diagrams. All the four sets of diagrams confirmed a continental rift setting for on-land basic rocks of $<13 \mathrm{Ma}$ age, with success rates of $71 \%-93 \%$ and $58 \%-90 \%$ for major-element and traceelement based diagrams, respectively. For the on-land basic rocks of $>13 \mathrm{Ma}$ age, major-element based diagrams also indicated a rift setting. However, one set of trace-element based discrimination diagrams indicated an arc to rift transition and the other set of trace- element based discrimination diagrams for the only sample from the Comondú arc, which has the required complete dataset, indicated an arc setting. All the four sets of discrimination diagrams indicated MORB setting (success rates 90\%-98\% and 100\% for major-element and trace-element based diagrams, respectively) for off-shore rocks (most of the samples were obtained from DSDP drilled sites in the Gulf of California and some dredged rock samples from the Gulf of California) with very high success rates. All the inferred tectonic settings from these four sets of new discrimination diagrams, in general, are in conformity with those reported in the literature based on other methods. The results show that these discrimination diagrams may successfully discriminate the original tectonic setting of comparatively younger and older on-shore rocks as well as sea-water altered deep-sea rocks and dredged material.
\end{abstract}

Keywords: Basic rocks, geochemistry, tectonic setting, arc, rifting, discrimination diagrams 


\section{Resumen}

Los diagramas de discriminación tectonomagmática han sido ampliamente utilizados en las últimas cuatro décadas para inferir la afiliación tectonomagmática de rocas antiguas. Hay numerosos diagramas discriminantes (bivariantes, ternarios, o de mayor dimensionalidad) en la literatura basados en la composición de los elementos mayores y traza. Las evaluaciones recientes del rendimiento de estos diagramas indican que los últimos cuatro conjuntos de diagramas tectonomagmáticos, en los que las fronteras tectónicas se determinan basándose en las estimaciones de probabilidades de cuatro configuraciones tectónicas (arco-isla, rift continental, islas oceánicas y dorsales oceánicas), han obtenido tasas de éxito muy alto. En este trabajo, hemos creado una amplia base de datos geoquímicos de rocas básicas obtenidas en tierra firme y en el Golfo de California, en el noroeste de México, y hemos aplicado estos diagramas recientes basados en las funciones discriminantes para deducir su contexto tectonomagmático original. Cada uno de estos cuatro conjuntos de diagramas (dos de elementos mayores y dos de elementos traza) contiene cinco diagramas. Cuando se introducen los datos de las rocas $<13 \mathrm{Ma}$ de edad recogidas en tierra firme, todos los tipos de diagramas confirman la dominante configuración de rift continental con tasas de éxito de 71\%-93\% y 58\%-90\% para las diagramas de elementos mayores y traza, respectivamente. Para las rocas básicas de la tierra firme de $>13$ Ma de edad, los diagramas de elementos mayores también indican una configuración tectónica dominante de rift continental. Sin embargo, un conjunto de diagramas de discriminación de elementos traza indica la transición de arco-isla a rift continental y otro conjunto de diagramas de elementos traza para una sola muestra del arco Comondú, indica configuración tectónica de arco-isla. Todos los tipos de diagramas de discriminación indican la configuración de MORB (tasas de éxito del 90\%-98\% y 100\% para los elementos mayores y traza, respectivamente) para las rocas del Golfo de California (predominantemente de puntos perforados en el programa DSDP y de algunas muestras de rocas dragadas) con tasas de éxito muy altas. En general, todas las configuraciones tectónicas inferidas a partir de estos cuatro conjuntos de diagramas de discriminación están en conformidad con los reportados en la literatura usando otros métodos. Los resultados muestran que estos diagramas de discriminación pueden discriminar correctamente la configuración tectonomagmática original de rocas muestreadas en tierra firme, ya sean más jóvenes o más antiguas, así como de las rocas alteradas por el agua del mar y los materiales de dragado.

Palabras clave: Rocas básicas, geoquímica, ambiente tectónico, arco-isla, rift continental, diagramas de discriminación.

\section{Introduction}

Tectonomagmatic discrimination diagrams are being widely used to infer the original tectonic setting of volcanic rocks (e.g., Pearce et al., 1977; Rollinson, 1993; Verma, 2010). These diagrams are developed on two major basic assumptions: (1) concentrations of the characteristic chemical elements being used in the discriminate diagrams show large differences in the rocks of different tectonic settings; and (2) these characteristic chemical elements of the rocks are relatively immobile from the period of rock formation to the present.

There are several major- and trace-element composition based diagrams for geochemical tectonic discrimination in the literature, which may be grouped as follows: (1) bivariate diagrams (Pearce and Gale, 1977; Pearce and Norry, 1979; Shervais, 1982; Pearce, 1982; Vasconcelos-F. et al., 1998, 2001); (2) ternary diagrams (Pearce and Cann, 1973; Pearce et al., 1977; Wood, 1980; Mullen, 1983; Meschede, 1986; Cabanis and Lecolle, 1989); (3) discriminant function based diagrams (Butler and Woronow, 1986; Pearce, 1976; Agrawal et al., 2004); and (4) multi-element discriminant function diagrams based on log-transformed ratios (Verma et al., 2006; Agrawal et al., 2008; Verma and Agrawal, 2011). All these discrimination diagrams have been developed based on a geochemical database of the volcanic rocks from known tectonic environments. In majority of the above mentioned diagrams, the tectonic discrimination boundaries were drawn by eye, i.e., were based on visual appearance of the clustering of data points of known tectonic settings, except in a few recent ones (Agrawal et al., 2004; Verma et al., 2006; Agrawal et al., 2008; Verma and Agrawal, 2011), in which the tectonic boundaries are determined based on probability estimates. Agrawal (1999) and Agrawal and Verma (2007) had already criticized the subjective use of eye for drawing tectonic field boundaries.

Recently, there are extensive evaluations of existing diagrams, which indicated highly variable success rates in discriminating the tectonic settings (Vermeesch, 2006, 2007; Verma et al., 2006, 2010, 2011; Sheth, 2008; Verma, 2010). Verma (2012) has recently documented serious statistical problems with both bivariate and ternary diagrams; in fact, for ternary diagrams he used Monte Carlo simulations to show their inadequacy and proposed log-ratio transformation as the best alternative to replace conventional ternary diagrams. Sheth (2008) evaluated some of the diagrams (Verma et al., 2006; Vermeesch, 2006) with data of ocean-island, arc and mid-ocean ridge lavas from the Indian Ocean and reported that the log-ratio transformation and linear discriminant analysis appear to be powerful methods in tectonomagmatic discrimination studies. Verma (2010) evaluated a large number of bivariate, ternary and multi-dimensional diagrams and inferred that the newer diagrams proposed during 2004-2011 provide more reliable results. Similarly, Verma et al. (2011) have successfully applied these multi-element based dis- 


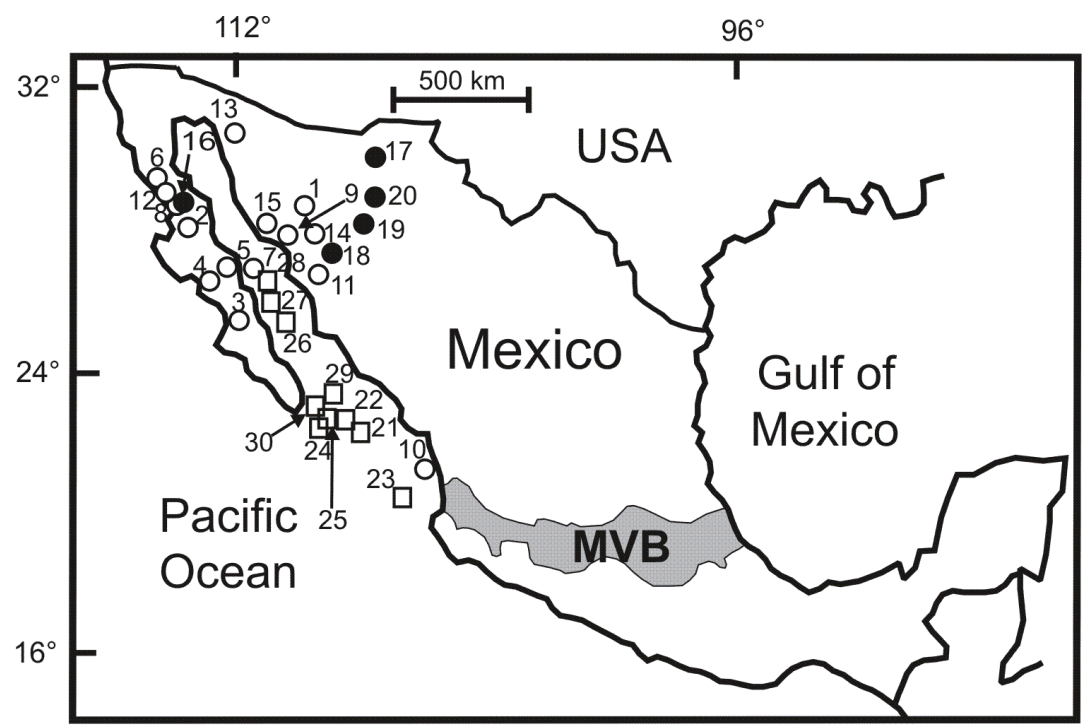

1. Hermosillo $(n=2)$

2. San Borja vol. field $(n=8)$

3. La Purisima vol. field $(n=2)$

4. Santa Clara vol. field $(n=6)$

5. San Ignacio vol field $(n=1)$

. San Ignacio vol. field $(n=1)$

7. Isla Tortuga $(n=1)$

. Jaraguay vol. field $(n=1)$

9. Sierra El Aguaje $(n=6)$

0. Isla Isabel $(n=10)$

1. Guaymas Basin $(n=2)$

2. San Carlos-Santa Catarina $(n=6)$

3. Pinacate Area,Sonora $(n=4)$

14. Sierra Libre $(n=2)$

15. Coastal Sonora $(n=2)$

16. Comondú Formation $(n=1)$

17. Sierra Madre Occident $(n=3)$

17. Sierra Madre Occidental $(n=3)$

18. Sierra Santa Ursula $(n-2)$

19. Suaqui Grande (

20. Sahuaripa $(n=5)$

21. DSDP site $482(n=176)$

22. DSDP site $483(n=132)$

23. DSDP site $485(n=93)$

24. DSDP site $474(n=76)$

25. DSDP site $475(n=11)$

26. DSDP site $477(n=33)$

27. DSDP site $478(n=50)$

28. DSDP site $481(n=4)$

29. Alarcon Rise $(n=29)$

30. Mouth of the Gulf of California $(n=4)$

Fig. 1.- Schematic map showing the locations of the basic rock samples used in this study. The open and filled circles represent the on-shore basic rocks of $<13 \mathrm{Ma}$ and $>13 \mathrm{Ma}$ ages, respectively. The squares represent off-shore basic rocks. (MVB: Mexican Volcanic Belt).

Fig. 1.- Mapa esquemático mostrando la ubicación de las muestras de rocas básicas utiizadas en este estudio. Los círculos blancos y negros representan las rocas básicas muestreadas en tierra de $<13$ Ma y de $>13$ Ma años de edad, respectivamente. Los cuadrados representan las rocas básicas muestreadas en el mar. (MVB: Cinturón Volcánico Mexicano).

criminant diagrams for basic rocks of Southern Mexico and Central America for inferring their tectonomagmatic origin.

In this article, we have evaluated the more recent and highly successful multi-element discriminant function diagrams with simple elemental ratio variables (Agrawal et al., 2004) and based on log-transformed ratios (Verma et al., 2006; Agrawal et al., 2008; Verma and Agrawal, 2011) with an application to the basic rocks of on-land and off-shore of northwest Mexico.

\section{Tectonic framework of the study area}

The late Cenozoic tectonic framework of northwestern Mexico has been discussed in detail by several researchers (for example, Rogers et al., 1985; Saunders et al., 1987; Verma,2000; Luhr et al., 1995; Calmus et al., 2003 ) and hence, only a brief discussion is provided here. The west coast of northwestern Mexico has been a convergent plate boundary since mid-Cretaceous. The eastward subduction of oceanic lithosphere beneath western North America continued from the Cretaceous to about 29 Ma (Mammerickx and Klitgord, 1982). Towards the western part of northwestern Mexico, subduction related magmatism is represented by batholitic granitoids between 90 and $40 \mathrm{Ma}$ (McDowell et al., 1997, 2001), whereas towards the east of the Baja California peninsula, a continuous subduction related magmatism during Eocene-Oligocene (between 38 and $23 \mathrm{Ma}$ ) has gener- ated important inland magmatism along the Sierra Madre Occidental belt (McDowell and Keizer, 1977; Stock and Lee, 1994; Benoit et al., 2002). Afterwards, during the Lower Miocene, the volcanic front shifted towards the west, forming the magmatic arc (the Comondú arc) all along the Baja California Peninsula. This volcanic belt had a longer activity between 24 and $12 \mathrm{Ma}$ in southern Baja California compared to northern Baja California where Miocene (21 to $16 \mathrm{Ma}$ ) volcanism constituted several volcanic fields. The subduction in this region ended at about 12.9 Ma (Mammerickx and Klitgord, 1982; Calmus et al., 2003). Afterwards, a transform boundary was developed between Pacific and North America plates parallel to the Pacific margin of Baja California (Spencer and Normark, 1979). Consequently, the tectonic setting has changed from subduction to rifting along the western margin of North America in Late-Cenozoic time (Grijalva-Noriega and Roldán-Quintana, 1998).

\section{Methodology}

We have prepared a database by compiling geochemical data of basic rocks of northwest Mexico from the published articles. For this purpose, we considered the basic rocks of on-land (Baja California, Baja California Sur and Sonora states of Mexico) and the off-shore (mainly from the DSDP sites of Gulf of California and a few from Alarcon Rise, and dredged rocks from three sites near the mouth of the Gulf of California and close to the 
East Pacific Rise) regions of northwest Mexico (Fig. 1). The geochemical data from the above mentioned regions were obtained from the published articles that were not included in any of the previous studies, in which the diagrams to be applied were proposed, i.e., not included in the databases used by Agrawal et al. (2004, 2008), Verma et al. (2006), and Verma and Agrawal (2011).

The literature sources for on-land geochemical data were as follows: Saunders et al. (1987); Luhr et al. (1995); Aguillón-Robles et al. (2001); Benoit et al. (2002); Calmus et al. (2003); Solano et al. (2005); Bellon et al. (2006); Pallares et al. (2007); Vidal-Solano et al. (2008); Till et al. (2009) ; Housh et al. (2010) ; and Calmus et al. (2011). The literature sources for the off-shore geochemical data were as follows: Lopez et al. (1978); Jochum and Verma (1996); Castillo et al. (2002); Flower et al. (2007); Morrison and Thompson (2007); Perfit et al. (2007); Saunders (2007); Saunders et al. (2007); and Zolotarev and Margolin (2007).

Based on the geochemical data, rock types were determined using SINCLAS computer program (Verma et al. 2002, 2003), with the Middlemost (1989) option for Fe-oxidation adjustment. This program requires the complete chemical analyses, involving all ten major elements (with total $\mathrm{Fe}$ as $\mathrm{Fe}_{2} \mathrm{O}_{3}$ or $\mathrm{FeO}$ ), for the rock samples.
Only basic rock types having $\left(\mathrm{SiO}_{2}\right)_{\text {adj }}<52 \%(\mathrm{Le}$ Bas et al., 1986) as inferred from the SINCLAS software were considered for this study. With this condition, we have left with the chemical data for only 102 basic rocks from the on-shore region. The number of samples (n) from the specific areas (Fig. 1) were as follows: Hermosillo $(\mathrm{n}=2)$, San Borja volcanic field $(\mathrm{n}=8)$, La Purísima volcanic field $(n=2)$, Santa Clara volcanic field $(n=6)$, San Ignacio volcanic field $(\mathrm{n}=1)$, San Quintín volcanic field $(\mathrm{n}=36)$, Isla Tortuga $(\mathrm{n}=1)$, Jaraguay volcanic field $(\mathrm{n}=1)$, Sierra El Aguaje $(n=6)$, Isla Isabel $(n=10)$, Guaymas Basin $(n=2)$, San Carlos-Santa Catarina $(n=6)$, Pinacate Area, Sonora $(n=4)$, Sierra Libre $(n=2)$, Coastal Sonora $(\mathrm{n}=2)$, Comondú Formation $(\mathrm{n}=1)$, Sierra Madre Occidental $(n=3)$, Sierra Santa Ursula $(n=2)$, Suaqui Grande $(n=2)$, and Sahuaripa $(n=5)$. Similarly, we have chemical data for 612 basic rocks from the offshore region (Fig. 1). These offshore chemical data are from the rocks of DSDP site $482(n=176)$, DSDP site $483(n=132)$, DSDP site 485 $(\mathrm{n}=93)$, DSDP site $474(\mathrm{n}=76)$, DSDP site $475(\mathrm{n}=11)$, DSDP site $477(n=33)$, DSDP site $478(n=50)$, DSDP site $481(n=4)$, Alarcon Rise lava from Gulf of California $(n=29)$, Mouth of the Gulf of California $(n=4$; dredged rocks from the mouth of the Gulf of California; including 8 subdivided parts of three of these dredged rocks), and

\begin{tabular}{|c|c|c|c|c|c|c|}
\hline \multirow{2}{*}{ Locality } & \multirow{2}{*}{$\begin{array}{c}\text { Discrimination } \\
\text { function discrimination } \\
\text { diagram }\end{array}$} & \multirow{2}{*}{$\begin{array}{l}\text { Total number } \\
\text { of samples }\end{array}$} & \multicolumn{4}{|c|}{ Number of discriminated samples $(\%)$} \\
\hline & & & IAB (1) & $\mathrm{CRB}(2)$ & OIB (3) & MORB (4) \\
\hline \multirow[t]{5}{*}{ On-land basic rocks $(<13 \mathrm{Ma})$} & $1-2-3-4$ & 89 & $0(0)$ & $63(71)$ & $4(4)$ & $22(25)$ \\
\hline & $1-2-3$ & 89 & $13(15)$ & $75(84)$ & $1(1)$ & --- \\
\hline & $1-2-4$ & 89 & $2(2)$ & $67(75)$ & --- & $20(23)$ \\
\hline & $1-3-4$ & 89 & $3(3)$ & --- & $50(56)$ & $36(41)$ \\
\hline & $2-3-4$ & 89 & --- & $76(86)$ & $3(3)$ & $10(11)$ \\
\hline \multirow[t]{5}{*}{ On-land basic rocks $(>13 \mathrm{Ma})$} & $1-2-3-4$ & 13 & $3(23)$ & $10(77)$ & 0 & 0 \\
\hline & $1-2-3$ & 13 & $4(31)$ & $9(69)$ & 0 & --- \\
\hline & $1-2-4$ & 13 & $5(38)$ & $8(62)$ & --- & 0 \\
\hline & $1-3-4$ & 13 & $5(38.5)$ & --- & $5(38.5)$ & $3(23)$ \\
\hline & $2-3-4$ & 13 & --- & $12(92)$ & 0 & $1(8)$ \\
\hline \multirow[t]{5}{*}{ Off-shore rocks } & $1-2-3-4$ & 608 & $4(1)$ & $9(1)$ & $46(8)$ & $549(90)$ \\
\hline & $1-2-3$ & 608 & $227(37)$ & $98(16)$ & $283(47)$ & --- \\
\hline & $1-2-4$ & 608 & $2(0.3)$ & $17(2.8)$ & --- & $589(96.9)$ \\
\hline & $1-3-4$ & 608 & $5(1)$ & --- & $38(6)$ & $565(93)$ \\
\hline & $2-3-4$ & 608 & --- & $6(1)$ & $51(8)$ & $551(91)$ \\
\hline \multirow[t]{5}{*}{ Sea-floor dredged material } & $1-2-3-4$ & 3 & 0 & 0 & 0 & 3 \\
\hline & $1-2-3$ & 3 & 3 & 0 & 0 & --- \\
\hline & $1-2-4$ & 3 & 0 & 0 & --- & 3 \\
\hline & $1-3-4$ & 3 & 0 & --- & 0 & 3 \\
\hline & $2-3-4$ & 3 & --- & 0 & 0 & 3 \\
\hline
\end{tabular}

Table 1.- Information on tectonomagmatic origin obtained from the set of five discriminant function based discrimination diagrams of Agrawal et al. (2004) for on-land and off-shore basic rocks of northwest Mexico. Boldface italic font indicates the inferred tectonic setting (IAB: island arc, CRB: continental rift, OIB: ocean-island, MORB: mid-ocean ridge).

Tabla 1.- Información sobre el origen tectonomagmático obtenido a partir del conjunto de los cinco diagramas de discriminación basados en la función discriminante de Agrawal et al. (2004) para las rocas básicas del noroeste de México estudiadas en este trabajo. La fuente negrita y cursiva indica el ambiente tectónico inferido (IAB: arco-isla, CRB: rift continental, OIB: isla oceánica, MORB: dorsal oceánica). 


\begin{tabular}{|c|c|c|c|c|c|c|}
\hline \multirow{2}{*}{ Locality } & \multirow{2}{*}{$\begin{array}{c}\text { Discrimination } \\
\text { function discrimination } \\
\text { diagram }\end{array}$} & \multirow{2}{*}{$\begin{array}{l}\text { Total number of } \\
\text { samples }\end{array}$} & \multicolumn{4}{|c|}{ Number of discriminated samples (\%) } \\
\hline & & & $\mathrm{IAB}(1)$ & CRB (2) & OIB (3) & MORB (4) \\
\hline \multirow[t]{5}{*}{ On-land basic rocks $(<13 \mathrm{Ma})$} & $1-2-3-4$ & 89 & $1(1)$ & $71(80)$ & $11(12)$ & $6(7)$ \\
\hline & $1-2-3$ & 89 & $1(1)$ & $83(93)$ & $5(6)$ & --- \\
\hline & $1-2-4$ & 89 & $1(1)$ & $81(91)$ & --- & $7(8)$ \\
\hline & $1-3-4$ & 89 & $9(10)$ & --- & $52(58)$ & $28(32)$ \\
\hline & $2-3-4$ & 89 & --- & $80(90)$ & $2(2)$ & $7(8)$ \\
\hline \multirow[t]{5}{*}{ On-land basic rocks (>13 Ma) } & $1-2-3-4$ & 13 & $3(23)$ & $10(77)$ & 0 & 0 \\
\hline & $1-2-3$ & 13 & $2(15)$ & $11(85)$ & 0 & --- \\
\hline & $1-2-4$ & 13 & $2(15)$ & $11(85)$ & --- & 0 \\
\hline & $1-3-4$ & 13 & $7(54)$ & --- & $3(23)$ & $3(23)$ \\
\hline & $2-3-4$ & 13 & --- & $12(92)$ & 0 & $1(8)$ \\
\hline \multirow[t]{5}{*}{ Off-shore rocks } & $1-2-3-4$ & 608 & $4(0.7)$ & $2(0.3)$ & $15(2.5)$ & $587(96.5)$ \\
\hline & $1-2-3$ & 608 & $5(1)$ & $37(6)$ & $566(93)$ & --- \\
\hline & $1-2-4$ & 608 & $5(1)$ & $4(1)$ & --- & $599(98)$ \\
\hline & $1-3-4$ & 608 & $4(1)$ & --- & $61(10)$ & $543(89)$ \\
\hline & $2-3-4$ & 608 & --- & $4(1)$ & $20(3)$ & $584(96)$ \\
\hline \multirow[t]{5}{*}{ Sea-floor dredged material } & $1-2-3-4$ & 3 & 0 & 0 & 0 & 3 \\
\hline & $1-2-3$ & 3 & 1 & 1 & 1 & --- \\
\hline & $1-2-4$ & 3 & 1 & 0 & --- & 2 \\
\hline & $1-3-4$ & 3 & 0 & --- & 0 & 3 \\
\hline & $2-3-4$ & 3 & --- & 0 & 0 & 3 \\
\hline
\end{tabular}

Table 2.- Information on tectonomagmatic origin obtained from the set of five discriminant function based discrimination diagrams of Verma et al. (2006) for on-land and off-shore basic rocks of northwest Mexico. Boldface italic font indicates the inferred tectonic setting (IAB: island arc, CRB: continental rift, OIB: ocean-island, MORB: mid-ocean ridge).

Tabla 2.- Información sobre el origen tectonomagmático obtenido a partir del conjunto de los cinco diagramas de discriminación basados en la función discriminante de Verma et al. (2006) para las rocas básicas del noroeste de México estudiadas en este trabajo. La fuente negrita y cursiva indica el ambiente tectónico inferido (IAB: arco-isla, CRB: rift continental, OIB: isla oceánica, MORB: dorsal oceánica).

other deep-sea samples (seamount, basin stations, etc; $\mathrm{n}=4)$. Natural log-transformed ratios for major elements were calculated as follows: $\ln \left(\mathrm{TiO}_{2} / \mathrm{SiO}_{2}\right)_{\text {adi }}, \ln \left(\mathrm{Al}_{2} \mathrm{O}_{3} /\right.$ $\left.\mathrm{SiO}_{2}\right)_{\text {adj }}, \ln \left(\mathrm{Fe}_{2} \mathrm{O}_{3} / \mathrm{SiO}_{2}\right)_{\text {adj }}, \ln \left(\mathrm{FeO} / \mathrm{SiO}_{2}\right)_{\text {adj }}, \ln \left(\mathrm{MnO} / \mathrm{SiO}_{2}\right)$ adj, $\ln \left(\mathrm{MgO} / \mathrm{SiO}_{2}\right)_{\text {adj }}, \ln \left(\mathrm{CaO} / \mathrm{SiO}_{2}\right)_{\text {adj }}, \ln \left(\mathrm{Na}_{2} \mathrm{O} / \mathrm{SiO}_{2}\right)_{\text {adj }}$, $\ln \left(\mathrm{K}_{2} \mathrm{O} / \mathrm{SiO}_{2}\right)_{\text {adj }}$, and $\ln \left(\mathrm{P}_{2} \mathrm{O}_{5} / \mathrm{SiO}_{2}\right)_{\text {adj }}$, in which $\left(\mathrm{SiO}_{2}\right)_{\text {adj }}$ was used as the common denominator.

In general, $\sim 13 \mathrm{Ma} \mathrm{BP}$ is considered as the end of subduction along the northwestern Mexico (Mammerickx and Klitgord, 1982; Calmus et al., 2003). We have grouped our on-land basic rock samples in rocks of $>13$ $\mathrm{Ma}$ ages (as subduction-arc magmatism) and $<13 \mathrm{Ma}$ (as rift magmatism) to identify their diverse tectonic settings. The diagrams of Agrawal et al. (2004) and Verma et al. (2006) are based on major-elements (the first with simple ratio variables and the second with log-transformation of ratio variables), whereas those of Agrawal et al. (2008) and Verma and Agrawal (2011) use log-transformed ratios of immobile-elements ( $\mathrm{La}, \mathrm{Sm}, \mathrm{Yb}, \mathrm{Nb}$, and $\mathrm{Zr}$ for the former and adjusted $\mathrm{TiO}_{2}, \mathrm{Nb}, \mathrm{V}, \mathrm{Y}$, and $\mathrm{Zr}$ for the latter). In all the above-mentioned four sets of new discriminant function based tectonomagmatic diagrams, there is no differentiation between the continental and oceanic arc settings, and the entire arc setting is represented by island arc setting (IAB). Based on the availability of the required chemical data in the above mentioned literature for the application of these four sets of recent tectonomagmatic discriminant function based diagrams for basic rocks, we obtained the final number of samples for each diagram as follows: (1) 89, 13, and 611 rock samples for on-land basic rocks of younger age $(<13 \mathrm{Ma})$, on-land basic rocks of older age ( $>13 \mathrm{Ma}$ ) and off-shore rocks (including 3 sea-floor dredged rocks), respectively, for the major-element concentrations based discrimination diagrams of Agrawal et al. (2004) and Verma et al. (2006); (2) 80, 13, and 8 rock samples for on-land basic rocks of younger age $(<13 \mathrm{Ma})$, on-land basic rocks of older age $(>13 \mathrm{Ma})$ and sea-floor dredged rocks (different parts of three rock samples), respectively, for the immobile trace-elemental concentrations based discrimination diagram of Agrawal et al. (2008); and finally, (3) 68, 1, and 78 rock samples for on-land basic rocks of younger age $(<13 \mathrm{Ma})$, on-land basic rocks of older age ( $>13 \mathrm{Ma})$ and off-shore rocks, respectively, for the immobile traceelement concentrations based discrimination diagram of Verma and Agrawal (2011). In the literature, chemical data for basic rocks are limited in comparison to acidic rocks. Chemical data for the older ( $>13$ Ma age) basic rocks are further lacking as compared to the basic rocks of $<13 \mathrm{Ma}$ age. Among the compiled chemical data for 


\begin{tabular}{|c|c|c|c|c|c|c|c|}
\hline \multirow[b]{2}{*}{ Locality } & \multirow{2}{*}{$\begin{array}{c}\text { Discrimination } \\
\text { function discrimination } \\
\text { diagram }\end{array}$} & \multirow{2}{*}{$\begin{array}{l}\text { Total number of } \\
\text { samples }\end{array}$} & \multicolumn{5}{|c|}{ Number of discriminated samples (\%) } \\
\hline & & & $\operatorname{IAB}(1)$ & CRB (2) & $\begin{array}{c}\text { CRB (2) + } \\
\text { OIB (3) }\end{array}$ & OIB (3) & MORB (4) \\
\hline \multirow[t]{5}{*}{ On-land basic rocks $(<13 \mathrm{Ma})$} & $1-2+3-4$ & 80 & $12(15)$ & --- & $64(80)$ & --- & $4(5)$ \\
\hline & $1-2-3$ & 80 & $14(17)$ & $46(58)$ & --- & $20(25)$ & --- \\
\hline & $1-2-4$ & 80 & $12(15)$ & $64(80)$ & --- & --- & $4(5)$ \\
\hline & $1-3-4$ & 80 & $11(14)$ & --- & --- & $61(76)$ & $8(10)$ \\
\hline & $2-3-4$ & 80 & --- & $52(65)$ & --- & $21(26)$ & $7(9)$ \\
\hline \multirow[t]{5}{*}{ On-land basic rocks (>13 Ma) } & $1-2+3-4$ & 13 & $4(31)$ & --- & $9(69)$ & --- & 0 \\
\hline & $1-2-3$ & 13 & $5(38.5)$ & $5(38.5)$ & --- & $3(23)$ & --- \\
\hline & $1-2-4$ & 13 & $4(31)$ & $9(69)$ & --- & --- & 0 \\
\hline & $1-3-4$ & 13 & $4(31)$ & --- & --- & $8(61)$ & $1(8)$ \\
\hline & $2-3-4$ & 13 & --- & $10(77)$ & --- & $2(15)$ & $1(8)$ \\
\hline \multirow[t]{5}{*}{ Altered glass } & $1-2-3-4$ & 2 & 1 & --- & 0 & --- & 1 \\
\hline & $1-2-3$ & 2 & 1 & 0 & --- & 1 & --- \\
\hline & $1-2-4$ & 2 & 1 & 0 & --- & --- & 1 \\
\hline & $1-3-4$ & 2 & 1 & --- & --- & 0 & 1 \\
\hline & $2-3-4$ & 2 & --- & 0 & --- & 0 & 2 \\
\hline \multirow[t]{5}{*}{ Margin } & $1-2+3-4$ & 3 & 1 & --- & 0 & --- & 2 \\
\hline & $1-2-3$ & 3 & 1 & 0 & --- & 2 & --- \\
\hline & $1-2-4$ & 3 & 1 & 0 & --- & --- & 2 \\
\hline & $1-3-4$ & 3 & 1 & --- & --- & 0 & 2 \\
\hline & $2-3-4$ & 3 & --- & 0 & --- & 0 & 3 \\
\hline \multirow[t]{5}{*}{ Core samples } & $1-2+3-4$ & 3 & 0 & --- & 0 & 0 & 3 \\
\hline & $1-2-3$ & 3 & 0 & 0 & --- & 3 & --- \\
\hline & $1-2-4$ & 3 & 0 & 0 & --- & --- & 3 \\
\hline & $1-3-4$ & 3 & 0 & --- & --- & 0 & 3 \\
\hline & $2-3-4$ & 3 & --- & 0 & --- & 0 & 3 \\
\hline
\end{tabular}

Table 3. Information on tectonomagmatic origin obtained from the set of five discriminant function based discrimination diagrams of Agrawal et al. (2008) for on-land and off-shore basic rocks of northwest Mexico. Boldface italic font indicates the inferred tectonic setting (IAB: island arc, CRB: continental rift, OIB: ocean-island, MORB: mid-ocean ridge).

Tabla 3. Información sobre el origen tectonomagmático obtenido a partir del conjunto de los cinco diagramas de discriminación basados en la función discriminante de Agrawal et al. (2008) para las rocas básicas del noroeste de México estudiadas en este trabajo. La fuente negrita y cursiva indica el ambiente tectónico inferido (IAB: arco-isla, CRB: rift continental, OIB: isla oceánica, MORB: dorsal oceánica).

on-land basic rocks, only one rock sample of $>13$ Ma age contained the necessary immobile trace element data to plot in the diagram of Verma and Agrawal (2011) which shows the dearth of trace element chemical data for the rocks of this region.

\section{Results and Discussion}

The compiled geochemical data of on-land and offshore basic rocks of northwest Mexico are plotted in all four sets of new discrimination diagrams (Agrawal et al., 2004, 2008; Verma et al., 2006; Verma and Agrawal, $2011)$ to infer the tectonomagmatic origin of these rocks. For each set of diagrams, five different plots were prepared, which provided a total of 20 diagrams. The samples in different tectonic setting fields were counted and their percentage range in each tectonic setting was calculated (wherever number of samples $>13$ ) and reported (Figs. 2-5; Tables 1-4). We discuss below only the dominant or most probable tectonic settings inferred by these diagrams for each group of rocks. All the indicated dominant tectonic setting are statistically significant because they are $>33.3 \%$ (being the simple "by chance" probability). The results are summarized in Tables 1-4. These results were fully consistent with those resulting from the application of computer program TecD (Verma and Rivera-Gómez, 2012).

\subsection{Tectonomagmatic origin of on-shore basic rocks of northwest Mexico}

Two sets of major-element (Agrawal et al., 2004, Fig. 2, Table 1; Verma et al., 2006, Fig. 3, Table 2) and two sets of immobile trace-element (Agrawal et al., 2008; Fig. 4; Table 3; Verma and Agrawal, 2011; Fig. 5; Table 4) based discrimination diagrams were applied for discrimination of island arc (IAB), continental rift (CRB), ocean-island (OIB) and mid-ocean ridge (MORB) tectonic settings. Out of the five diagrams in each of the two sets of major-element based diagrams, the first diagram 
Fig. 2.-Application of the major-element discriminant function based discrimination diagrams of Agrawal et al. (2004) for basic rocks from northwestern Mexico. (IAB: island arc, CRB: continental rift, OIB: oceanisland, MORB: mid-ocean ridge).

Fig. 2.-Aplicación de los diagramas discriminantes basados en elementos mayores y en la función de discriminación de Agrawal et al. (2004) para rocas básicas del noroeste de México. (IAB: arco-isla, CRB: rift continental, OIB: isla oceánica, MORB: dorsal oceánica).
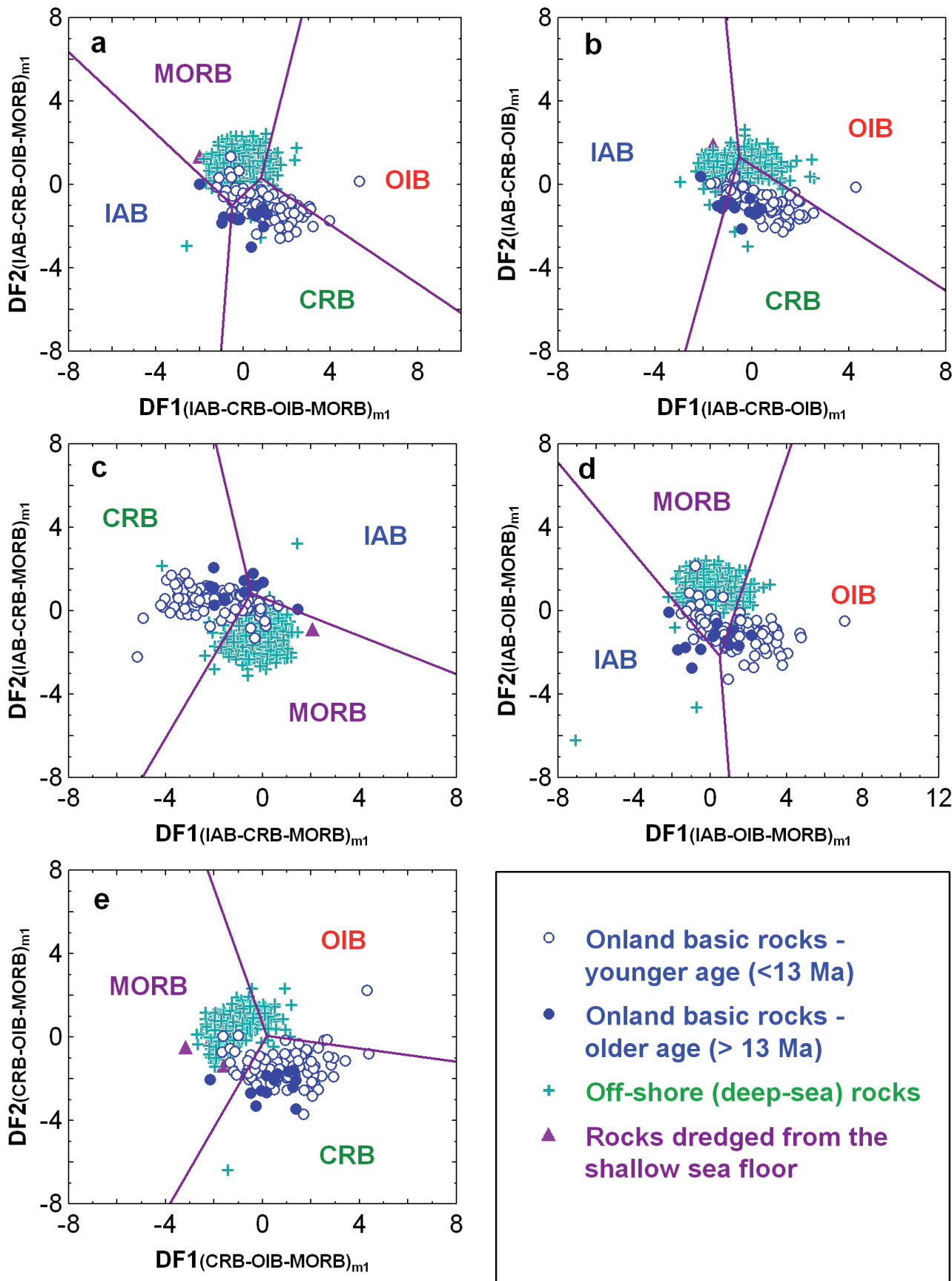

- Onland basic rocks younger age (<13 Ma)

- Onland basic rocks older age (>13 Ma)

+ Off-shore (deep-sea) rocks

- Rocks dredged from the shallow sea floor contains four tectonic settings and other four diagrams with three settings at a time.

The first set of major-element based discrimination diagrams of Agrawal et al. (2004; Fig. 2; Table 1) indicated the tectonic setting of continental rift (success rates of $71 \%-86 \%$ ) for on-land basic rocks of $<13 \mathrm{Ma}$ age (a total of 89 samples were available). For on-land basic rocks of $>13 \mathrm{Ma}$ age, these diagrams also indicated the tectonic setting of continental rift although the total number of samples was much less (only 13, of which 8 to 12 plotted in CRB). In diagrams with both CRB and IAB settings (Fig. 2a-c), the samples were divided in these two tectonic settings, i.e., 8 to 10 samples plotted in $\mathrm{CRB}$ and the remaining 5 to 3 in IAB (Table 1).
When we used exactly the same samples as for the first set, the second set of major-element based diagrams of Verma et al. (2006; Fig.3; Table 2) also revealed the dominant continental rift setting with still higher success rates (80\%-93\%) for on-land basic rocks of $<13$ Ma age than the Agrawal et al. (2004) diagrams. For onland basic rocks of $>13 \mathrm{Ma}$ age, similar to the first set of diagrams, these second set of major-element based diagrams indicated the tectonic setting of continental rift (10 to 12 samples out of 13 plotted in the rift field; Fig. 3; Table 2).

The first set of immobile trace element based diagrams of Agrawal et al. (2008; Fig. 4; Table 3) was also applied for IAB, CRB, OIB, and MORB (all five diagrams 

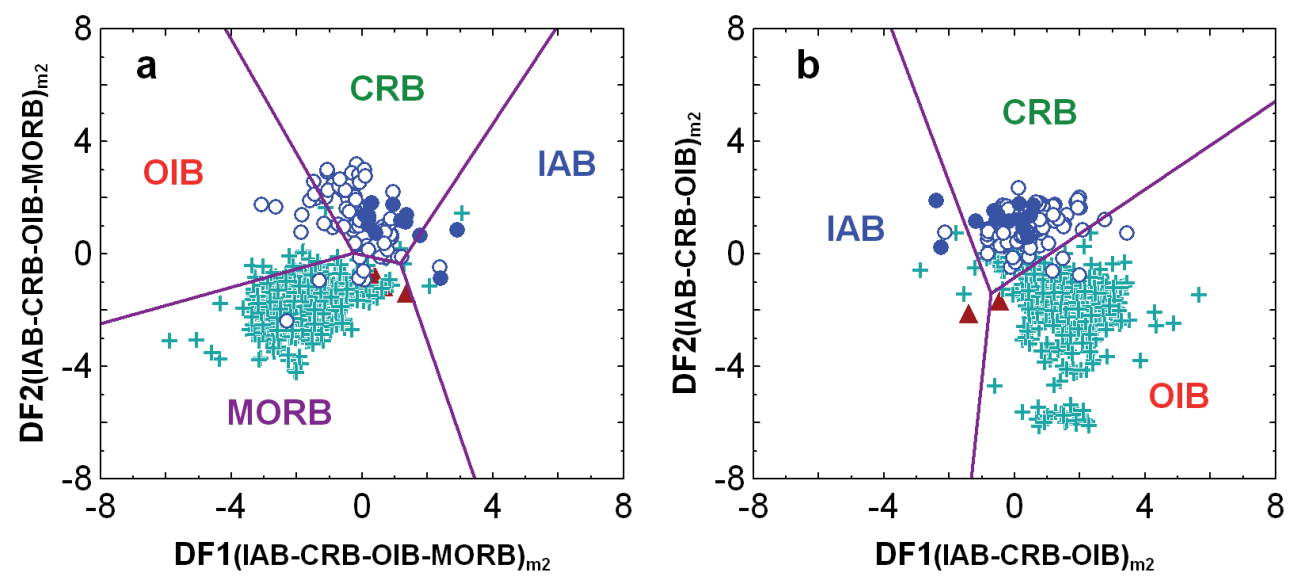

Fig. 3.-Application of the major-element discriminant function based discrimination diagrams of Verma et al. (2006) for basic rocks from northwestern Mexico. (IAB: island arc, CRB: continental rift, OIB: oceanisland, MORB: mid-ocean ridge).

Fig. 3.-Aplicación de los diagramas discriminantes basados en elementos mayores y en la función de discriminación de Verma et al. (2006) para rocas básicas del noroeste de México. (IAB: arco-isla, CRB: rift continental, OIB: isla oceánica, MORB: dorsal oceánica).
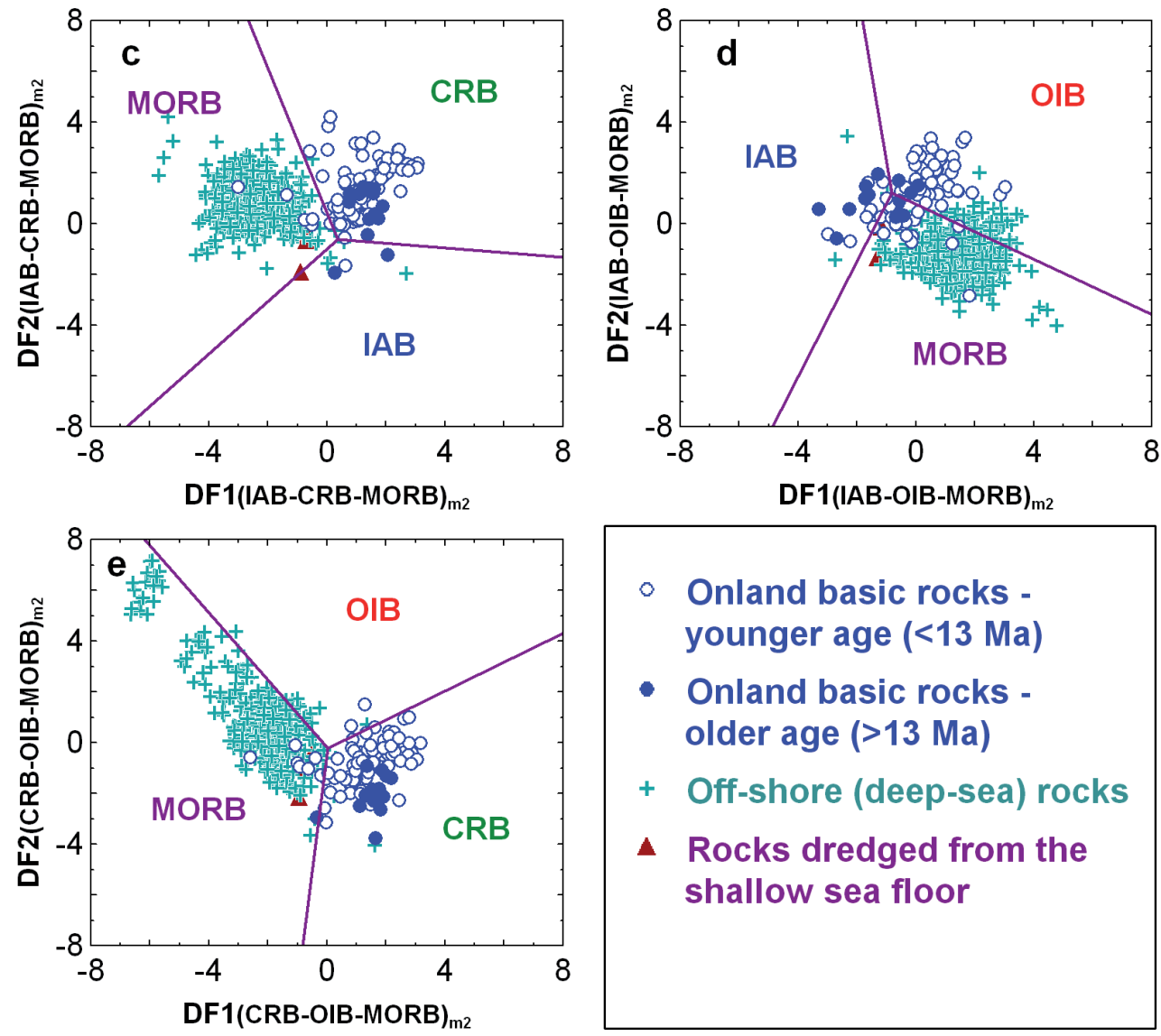

- Onland basic rocks younger age (<13 $\mathrm{Ma})$

- Onland basic rocks older age (>13 Ma)

+ Off-shore (deep-sea) rocks

- Rocks dredged from the shallow sea floor

contains three tectonic settings at a time). The indicated tectonic settings are: (1) the dominant continental rift setting (success rates of $58 \%-80 \%$ ) for 80 samples of on-land basic rocks of $<13 \mathrm{Ma}$ age; (2) when there is no individual CRB setting in the diagrams (Figs. 4a and $4 d$ ), the on-land basic rocks of $<13$ Ma age have plotted, respectively, in the combined tectonic field settings of $\mathrm{CRB}+\mathrm{OIB}$ (with a high success rate of $80 \%$ ) and OIB (with a high success rate of $76 \%$ ); and (3) continental rift tectonic setting ( 5 to 10 samples out of 13 plotted in this field; Fig. 4; Table 3) for on-land basic rocks of $>13$ Ma age, with 4 to 5 samples (out of 13) plotting in the arc field.
Finally, the second set of immobile-element based diagrams of Verma and Agrawal (2011; Fig. 5; Table 4) was also applied for IAB, CRB, OIB, and MORB (three settings at a time in all the five diagrams). These immobileelement based diagrams of Verma and Agrawal (2011; Fig. 5; Table 4) complies the requirement of normal distribution of the log-ratio variables. This was achieved by identification and elimination of outlier data points by using the software DODESSYS (Verma and DíazGonzález, 2012), which allows the application of the multiple-test method initially proposed by Verma (1997) and uses new precise and accurate critical values for discordancy tests (Barnett and Lewis, 1994; Verma and Qui- 


\begin{tabular}{|c|c|c|c|c|c|c|c|}
\hline \multirow{2}{*}{ Locality } & \multirow{2}{*}{$\begin{array}{c}\text { Discrimination } \\
\text { function discrimination } \\
\text { diagram }\end{array}$} & \multirow{2}{*}{$\begin{array}{c}\text { Total number of } \\
\text { samples }\end{array}$} & \multicolumn{5}{|c|}{ Number of discriminated samples (\%) } \\
\hline & & & $\mathrm{IAB}(1)$ & CRB (2) & $\begin{array}{c}\text { CRB (2) + } \\
\text { OIB (3) }\end{array}$ & OIB (3) & MORB (4) \\
\hline \multirow[t]{5}{*}{ On-land basic rocks $(<13 \mathrm{Ma})$} & $1-2+3-4$ & 68 & $3(4)$ & --- & $60(89)$ & --- & $5(7)$ \\
\hline & $1-2-3$ & 68 & $6(9)$ & $45(66)$ & --- & $17(25)$ & --- \\
\hline & $1-2-4$ & 68 & $3(4)$ & $61(90)$ & --- & --- & $4(6)$ \\
\hline & $1-3-4$ & 68 & $3(4)$ & --- & --- & $52(77)$ & $13(19)$ \\
\hline & $2-3-4$ & 68 & --- & $45(66)$ & --- & $18(27)$ & $5(7)$ \\
\hline \multirow[t]{5}{*}{ On-land basic rocks (>13 Ma) } & $1-2+3-4$ & 1 & 1 & --- & 0 & --- & 0 \\
\hline & $1-2-3$ & 1 & 1 & 0 & --- & 0 & --- \\
\hline & $1-2-4$ & 1 & 1 & 0 & --- & --- & 0 \\
\hline & $1-3-4$ & 1 & 1 & --- & --- & 0 & 0 \\
\hline & $2-3-4$ & 1 & --- & 0 & --- & 0 & 1 \\
\hline \multirow[t]{5}{*}{ Off-shore rocks } & $1-2-3-4$ & 78 & $0(0)$ & -- & $0(0)$ & --- & $78(100)$ \\
\hline & $1-2-3$ & 78 & $75(96)$ & $3(4)$ & -- & $0(0)$ & --- \\
\hline & $1-2-4$ & 78 & $0(0)$ & $0(0)$ & --- & -- & $78(100)$ \\
\hline & $1-3-4$ & 78 & $0(0)$ & -- & --- & $0(0)$ & $78(100)$ \\
\hline & $2-3-4$ & 78 & --- & $0(0)$ & --- & $0(0)$ & $78(100)$ \\
\hline
\end{tabular}

Table 4. Information on tectonomagmatic origin obtained from the set of five discriminant function based discrimination diagrams of Verma and Agrawal (2011) for on-land and off-shore basic rocks of northwest Mexico. Boldface italic font indicates the inferred tectonic setting (IAB: island arc, CRB: continental rift, OIB: ocean-island, MORB: mid-ocean ridge).

Tabla 4. Información sobre el origen tectonomagmático obtenido a partir del conjunto de los cinco diagramas de discriminación basados en la función discriminante de Verma y Agrawal (2011) para las rocas básicas del noroeste de México estudiadas en este trabajo. La fuente negrita y cursiva indica el ambiente tectónico inferido (IAB: arco-isla, CRB: rift continental, OIB: isla oceánica, MORB: dorsal oceánica).

roz-Ruiz, 2006a, 2006b, 2008; Verma et al., 2008). The indicated tectonic settings are as follows: continental rift setting (66\%-90\%) for on-land basic rocks of $<13$ Ma age and island-arc setting for the only one on-land basic rock sample of $>13$ Ma age.

The observed tectonomagmatic settings by the new discriminant function based tectonomagmatic settings for younger $(<13 \mathrm{Ma}$ age) on-land basic rocks are fully in concordance with those reported in the literature. The two sets of major-element (success rates of $71 \%-86 \%$, Agrawal et al., 2004; success rates of 80\%-93\%, Verma et al., 2006) and two sets of trace-element (success rates of 58\%-80\%, Agrawal et al., 2008; success rates of 66\%90\%, Verma and Agrawal, 2011) based discrimination diagrams confirm the dominant continental rift setting (CRB; Tables 1-4; Figs. 2-5) for on-land basic rocks of $<13 \mathrm{Ma}$ age. This is in agreement with that of the literature. The subduction of oceanic (Pacific) lithosphere beneath western North America continued from Cretaceous and ended at 12.9 Ma (Mammerickx and Klitgord, 1982; Calmus et al., 2003). After this period, during LateCenozoic, a transform boundary is developed between Pacific and North America plates parallel to the Pacific margin of Baja California (Spencer and Normark, 1979) which resulted in change of the tectonic setting from subduction to rifting along the western margin of North America (Grijalva-Noriega and Roldán-Quintana, 1998).

For the on-land basic rocks of $>13$ Ma age, we may draw the following inferences: (1) the major-element based diagrams of Agrawal et al. (2004; Table 1; Fig. 2) and Verma et al. (2006; Table 2; Fig. 3) indicated continental rift setting for the limited number of samples (only 13 ) with high success rates $(62 \%-92 \%$ and $77 \%-92 \%$, respectively), with most of the remaining samples plotting in the island arc setting; and (2) the trace-element based discrimination diagrams of Agrawal et al. (2008; Table 3; Fig. 4) and Verma and Agrawal (2011; Table 4; Fig. $5)$ provided less clear results, because, in the Agrawal et al. (2008) set, the samples indicated a continental rift setting with much lower success rates (38\%-77\%) and in the Verma and Agrawal (2011) set, the only sample (from the Comondú arc) plotted in the island arc field. In both of these two sets of the trace-element based diagrams (Agrawal et al., 2008; Verma and Agrawal, 2011) only two out of five diagrams in each set have both IAB and CRB fields (Table 3 and 4; Fig. 4 and 5). In these two diagrams of Agrawal et al. (2008), one diagram (Fig. 4b) indicated a combined CRB-IAB setting (equal number of samples plotted in both $\mathrm{CRB}$ and IAB; Table 3) and the other diagram (Fig. 4c) indicated a dominant CRB setting ( 9 out of 13 samples plotted in CRB and the remaining 4 samples in the IAB field). We may, therefore, conclude that these diagrams (Agrawal et al., 2008) may be interpreted as indicating a transition from an arc to rift setting.

The only rock sample with complete dataset for the Verma and Agrawal (2011) diagrams is plotted in the IAB field (Table 4 and Fig. 5a-d); whereas in the fifth diagram (Fig. 5e), where IAB field is not there, this sample is plot- 

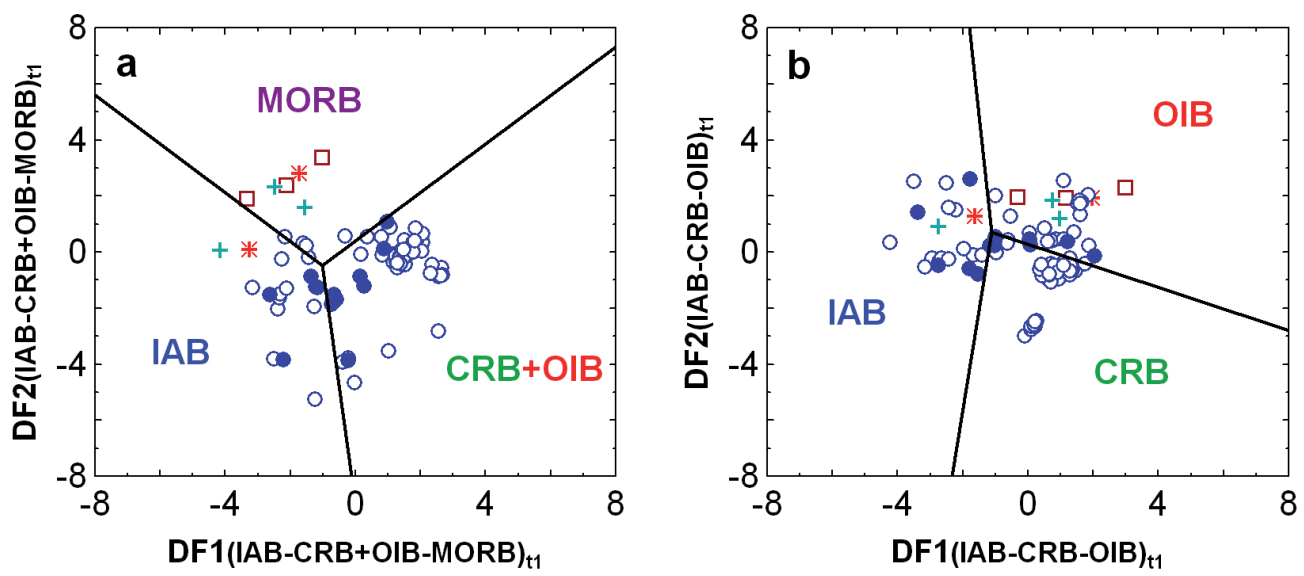

Fig. 4.-Application of the traceelement discriminant function based discrimination diagrams of Agrawal et al. (2008) for basic rocks from northwestern Mexico. (IAB: island arc, CRB: continental rift, OIB: ocean-island, MORB: mid-ocean ridge).

Fig. 4.-Aplicación de los diagramas discriminantes basados en elementos traza y en la función de discriminación de Agrawal et al. (2008) para rocas básicas del noroeste de México. (IAB: arcoisla, CRB: rift continental, OIB: isla oceánica, MORB: dorsal oceánica).
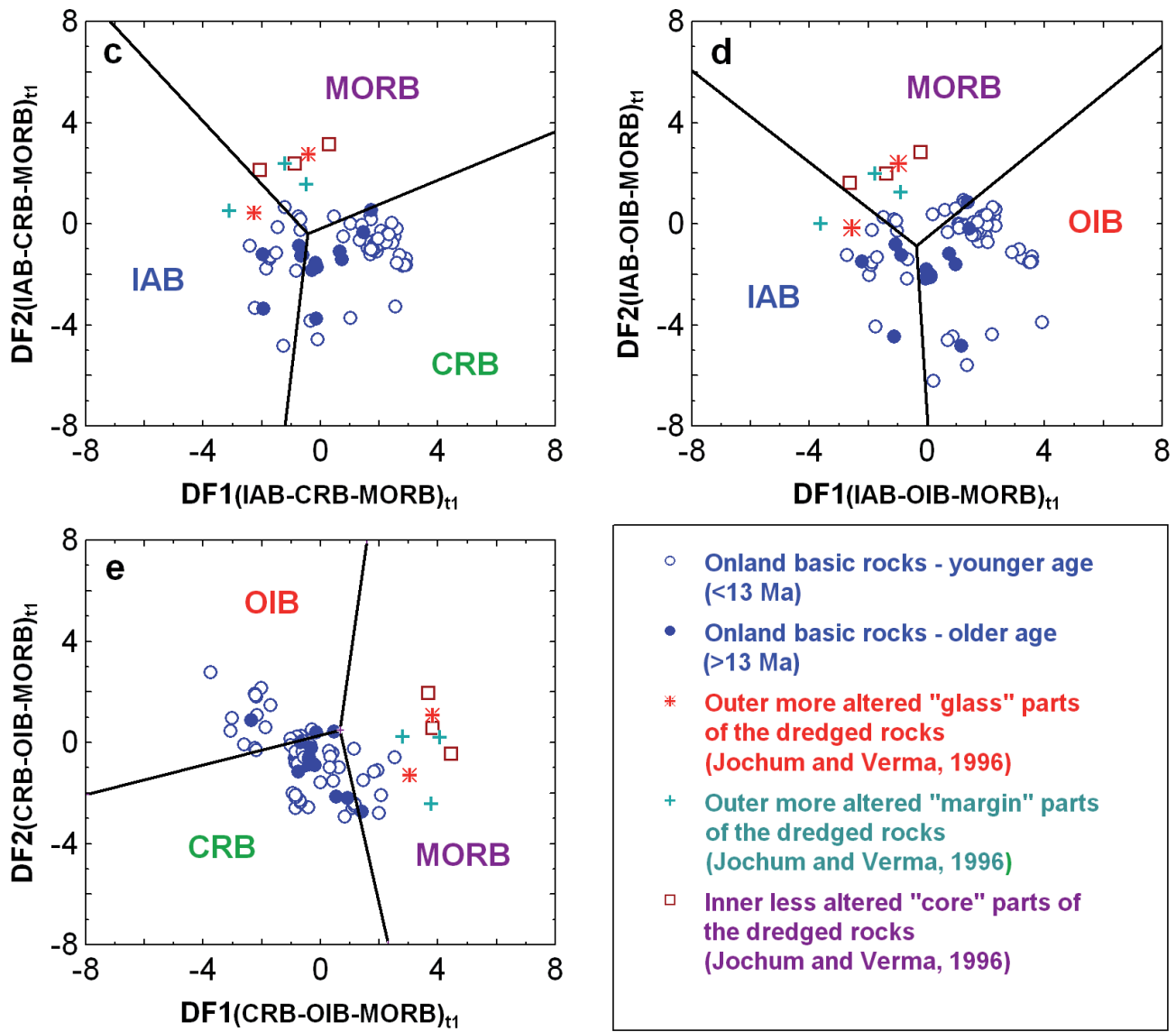

\begin{tabular}{|c|c|}
\hline 0 & $\begin{array}{l}\text { Onland basic rocks - younger age } \\
(<13 \mathrm{Ma})\end{array}$ \\
\hline • & $\begin{array}{l}\text { Onland basic rocks - older age } \\
\text { (>13 Ma) }\end{array}$ \\
\hline * & $\begin{array}{l}\text { Outer more altered "glass" parts } \\
\text { of the dredged rocks } \\
\text { (Jochum and Verma, 1996) }\end{array}$ \\
\hline+ & $\begin{array}{l}\text { Outer more altered "margin" parts } \\
\text { of the dredged rocks } \\
\text { (Jochum and Verma, 1996) }\end{array}$ \\
\hline 口 & $\begin{array}{l}\text { Inner less altered "core" parts of } \\
\text { the dredged rocks } \\
\text { (Jochum and Verma, 1996) }\end{array}$ \\
\hline
\end{tabular}

ted in the MORB field.

Among the 13 older on-land basic rocks ( $>13 \mathrm{Ma})$, nine rocks belongs to Southern Sonora (19-28 Ma; Till et al., 2009), three rocks (27-45 Ma age; Albrecht and Goldstein, 2000) belong to Sierra Madre Occidental, northwestern Mexico and the one rock (20.06 Ma age; Pallares et al., 2007) belongs to Comondú Formation (from Cataviña; Pallares et al., 2007). It is reported that the Sierra Madre Occidental and Comondú arc were formed as the result of the subduction of oceanic lithosphere beneath western North America during Eocene-Oligocene and Lower Miocene respectively (McDowell and Keizer, 1977; Stock and Lee, 1994; Benoit et al., 2002). Recently, Till et al.
(2009) have reported that mafic volcanic rocks erupted in southern Sonora from 27 to 8 Ma have continental arc signature and appear to be derived from the metasomatized sub-arc mantle below Sonora. They were also of the opinion that the geochemistry of the rocks of Sonora is not consistent with the predictions of petrotectonic models and contrasts with central and southern Baja. The chemical data reported for basic rocks in the article of Till et al. (2009) were already included in the database of this work. As discussed above, all the four recent tectonic discriminate diagrams for basic rocks (Agrawal et al., 2004; Verma et al., 2006; Agrawal et al., 2008; Verma and Agrawal, 2011) have indicated the continental rift 
Fig. 5.- Application of the traceelement discriminant function based discrimination diagrams of Verma and Agrawal (2011) for basic rocks from northwestern Mexico. The samples marked with red color are outliers. (IAB: island arc, CRB: continental rift, OIB: ocean-island, MORB: midocean ridge).

Fig. 5.- Aplicación de los diagramas discriminantes basados en elementos traza y en la función de discriminación de Verma y Agrawal (2011) para rocas básicas del noroeste de México. Las muestras marcadas en color rojo son los valores desviados. (IAB: arco-isla, CRB: rift continental, OIB: isla oceánica, MORB: dorsal oceánica).
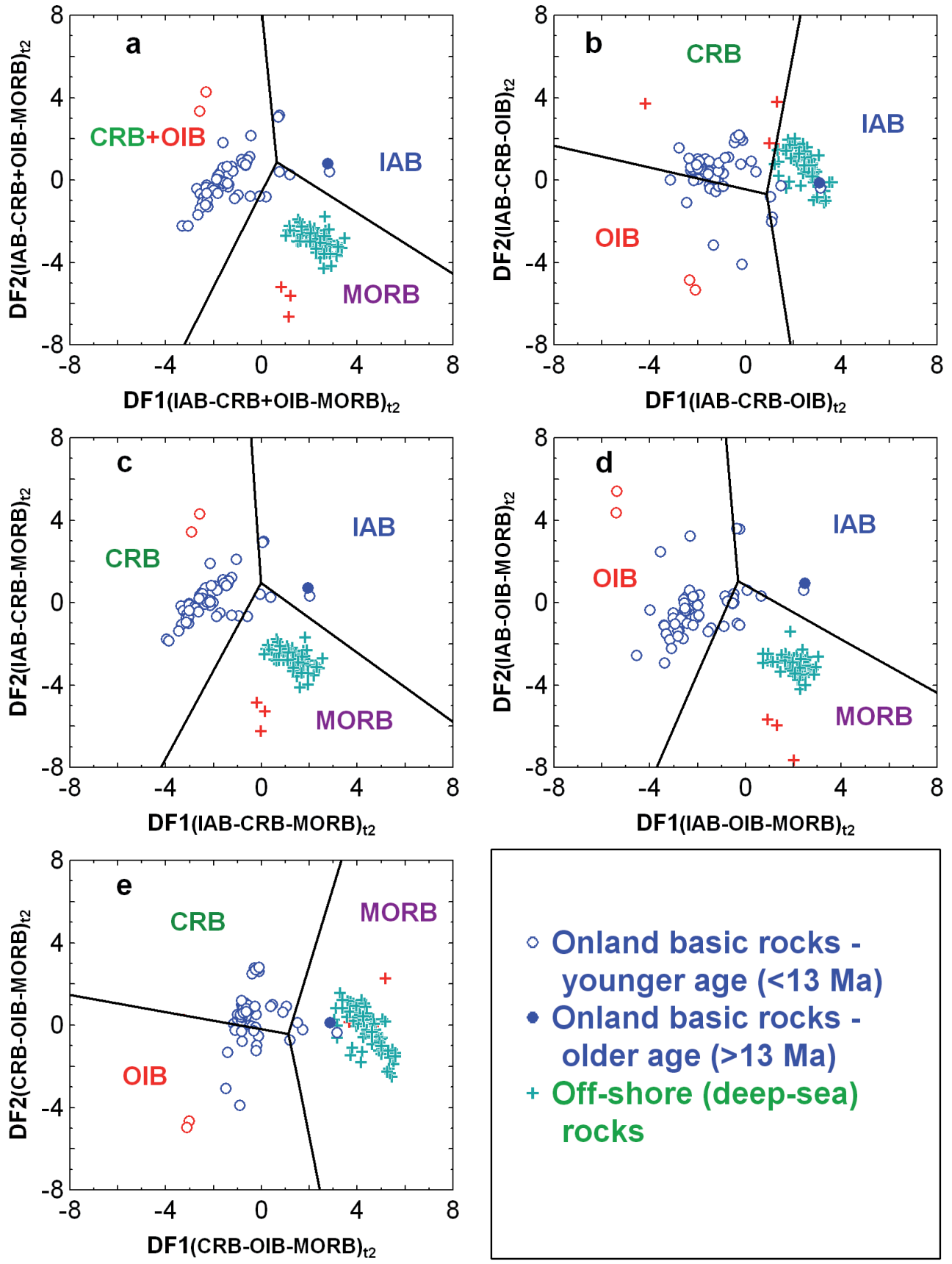

- Onland basic rocks younger age (<13 Ma)

- Onland basic rocks older age (>13 Ma)

+ Off-shore (deep-sea) rocks

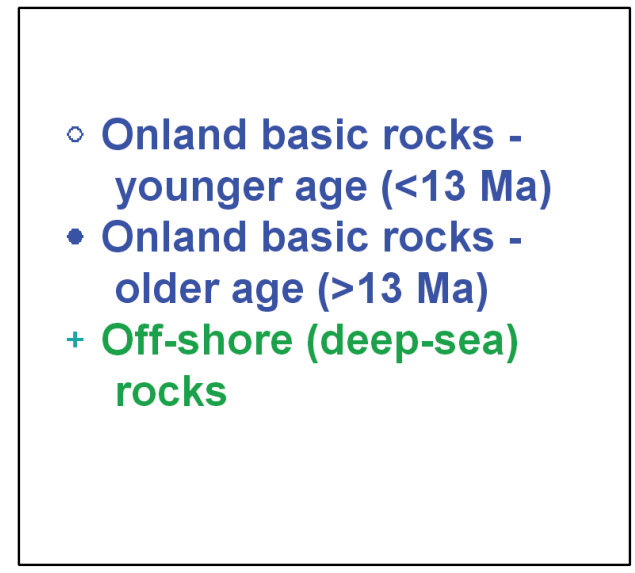

setting (CRB) for rocks of $<13 \mathrm{Ma}$. For older rocks $(>13$ Ma) also, three sets of diagrams (Agrawal et al., 2004; Verma et al., 2006; Agrawal et al., 2008) indicated a rift setting, with the exception of Verma and Agrawal (2011) diagrams which indicated an arc setting for the unique sample from the Comundú arc.

For further clarity, we have applied the new discriminant-function-based multi-dimensional diagrams for acid (Verma et al., 2012) and intermediate rocks (Verma and Verma, 2013) reported in Till et al. (2009). The tectonic discriminant diagrams for both acid and intermediate rocks have indicated a dominant rift setting. This is consistent with the inferred dominant rift setting by the four sets of discriminate diagrams for basic rocks $<13 \mathrm{Ma}$ and three sets of diagrams for basic rocks $>13$ Ma age, discussed above, although Till et al. (2009) envisioned an arc setting for mafic volcanic rocks (27 to $8 \mathrm{Ma}$ age) from Sonora. Our results thus do not support the contention of Till et al. (2009) regarding the tectonic setting of their data.

Because the older samples ( $>13 \mathrm{Ma}$ ) come from widely different localities (12 from locations 17-20 in mainland Mexico and one from location 16 in Baja California; Fig. 1) and the rock samples from locations 17-20 might be away from the possible arc environment, they have not indicated a concrete arc setting. However, it is interesting 
to note that in all four sets of diagrams (Figs. 2-5), the only sample from the Comundú arc consistently plots in the arc field. This emphasizes the need of more data from the Comundú arc to understand the functioning of these diagrams.

\subsection{Tectonomagmatic origin of off-shore basic rocks of northwest Mexico}

The first set of major-element based discrimination diagrams of Agrawal et al. (2004; Fig. 2; Table 1) have indicated the tectonic setting of MORB (success rates of 90\%-97\%) for the off-shore rocks off northwest Mexico. When there is no MORB setting in the diagram (Fig. 2b), the samples occupied OIB (47\%) and IAB (37\%) settings.

When we used exactly the same samples as for the first set, the second set of major-element based diagrams of Verma et al. (2006; Fig.3; Table 2) also indicated the MORB setting (88\%-98\%). When in a diagram there is no tectonic setting of MORB (Fig. 3b), 93\% of these rock samples occupied OIB setting.

Because the required chemical data for all five trace elements ( $\mathrm{La}, \mathrm{Sm}, \mathrm{Nb}, \mathrm{Yb}$ and $\mathrm{Th}$ ) were not available for any of the off-shore rocks, the first set of immobileelement based diagrams of Agrawal et al. (2008; Fig. 4; Table 3) could not be applied for these rocks.

Finally, the second set of immobile-element based diagrams of Verma and Agrawal (2011; Fig. 5a,c-e; Table 4) indicated MORB tectonic setting (100\%) for these offshore rocks. When MORB setting is missing from a diagram (Fig. 5b), all these off-shore rock samples occupied IAB setting.

Thus, two sets of major-element based discrimination diagrams of Agrawal et al. (2004) and Verma et al. (2006; Figs. 2-3; Tables 1-2) and the immobile-trace element based diagrams of Verma et al. (2011; Fig. 5; Table 4) indicated the tectonic setting of MORB for off-shore basement rocks of DSDP drilled core locations in the Gulf of California.

We have included in the present database the wholerock chemical data of three rocks dredged from the locations close to the East Pacific Rise near the mouth of the Gulf of California (Lopez et al., 1978; Jochum and Verma, 1996). Lopez et al. (1978) have reported that these rocks are geochemically similar to other samples from the East Pacific Rise and surrounding seamounts, and are characterized by sea-water alteration effects. The available whole-rock chemical data of these rocks allowed us to apply only major-element based diagrams (Agrawal et al., 2004; Verma et al., 2006). All the three rock samples dredged from the sea-floor near the mouth of the Gulf of California occupied the field of MORB setting in these major element based diagrams (Figures 2-3; Tables 1-2).
Earlier, Lopez et al. (1978) have reported that these samples are clustered in the field of ocean floor basalts in the discrimination diagrams of Pearce and Cann (1973) and Pearce (1975). We have also included in the present work the detailed chemical analysis of the individually sampled three parts (the inner less altered "core", the outer more altered "margin" and "glass" from the outer part) of each of these three dredged rocks (Jochum and Verma, 1996). The available geochemical data for these three parts of each of three dredged rocks allowed us to apply only the set of immobile element based diagrams of Agrawal et al. (2008). These diagrams indicated a MORB setting for inner less altered "core" and outer altered "margin" parts, and combined island-arc and MORB settings for altered "glass" parts of these three rocks.

Thus, all diagrams - the two sets of new major-element (Agrawal et al., 2004; Verma et al., 2006) and two sets of trace-element (Agrawal et al., 2008; Verma and Agrawal, 2011) based discrimination diagrams - confirm the MORB setting for off-shore rocks. Majority of these offshore rocks are the basement rocks from the DSDP drilled locations. Concentrations of geochemical elements will be effected by sea-water alteration at these great depths of the oceans as observed in the dredged rocks from the locations close to the East Pacific Rise near the mouth of the Gulf of California (Lopez et al., 1978; Jochum and Verma, 1996). In spite of sea-water alteration effects in geochemistry of these three dredged rocks (Lopez et al., 1978; Jochum and Verma, 1996), the new tectonomagmatic discrimination diagrams are able to identify their tectonomagmatic origin as MORB. These results show that these four sets of new tectonomagmatic discrimination diagrams may successfully discriminate the original tectonic setting of deep-sea basement rocks and dredged material in spite the possibility of sea-water alteration effects in their geochemical concentrations.

\section{Conclusions}

The recent discriminant function based discrimination diagrams (Agrawal et al., 2004) along with the logtransformed ratios of chemical variables (Verma et al., 2006; Agrawal et al., 2008; Verma and Agrawal, 2011), in which the tectonic boundaries are determined based on probability estimates, are more powerful and have shown very high success rates in finding the tectonomagmatic origin of on-shore and offshore basic rocks of northwest Mexico. These diagrams have indicated: (1) for on-land basic rocks of $<13$ Ma age, a continental rift setting (with high success rates); (2) for on-land basic rocks of $>13 \mathrm{Ma}$ age, a continental rift setting from major-element based diagrams (with lower success rates than for the younger rocks) and an arc to rift transitional setting from one set 
of immobile trace-element based diagrams; (3) the only one sample of older age $(>13 \mathrm{Ma})$ from the Comundú arc consistently indicated an arc setting in all diagrams; and (4) MORB setting for off-shore rocks. All these inferred tectonic settings are generally in conformity with those reported in the literature. This work suggests that these new diagrams prepared by relevant statistical methodologies can be successfully applied to infer the tectonic setting of fresh as well as altered basic rocks.

\section{Acknowledgements}

We thank Dr. Mike de Villiers, Prof. Salil Agrawal and an anonymous reviewer for highly appreciating our work and for providing valuable comments for improving the earlier version of the manuscript. Similarly, we are grateful to Dr. Surendra P. Verma for his suggestions for improving the chemical database used in this work and for his valuable comments on the earlier version of the manuscript.

\section{References}

Agrawal, S. (1999): Geochemical discrimination diagrams: a simple way of replacing eye-fitted boundaries with probability based classifier surfaces. Journal of the Geological Society of India 54, 335-346.

Agrawal, S., Verma, S.P. (2007): Comment on "Tectonic classification of basalts with classification trees" by Pieter Vermeesch (2006). Geochimica et Cosmochimica Acta 71, 3388-3390. doi:10.1016/j. gca.2007.03.036

Agrawal, S., Guevara, M., Verma, S.P. (2004): Discriminant analysis applied to establish major-element field boundaries for tectonic varieties of basic rocks. International Geology Review 46, 575-594. doi:10.2747/0020-6814.46.7.575

Agrawal, S., Guevara, M., Verma, S.P. (2008): Tectonic discrimination of basic and ultrabasic rocks through log-transformed ratios of immobile trace elements. International Geology Review, 50: 1057-1079. doi:10.2747/0020-6814.50.12.1057

Aguillón-Robles, A., Calmus, T., Benoit, M., Bellon , H., Maury, R.C., Cotten, J., J., B., Michaud, F. (2001): Late Miocene adakites and Nbenriched basalts from Vizcaino Peninsula, Mexico: Indicators of East Pacific Rise subduction below southern Baja California? Geology 29, 531-534. doi:10.1130/0091-7613(2001)029<0531:LMAANE $>2.0$. $\mathrm{CO} ; 2$

Albrecht, A., Goldstein, S.L. (2000): Effects of basement composition and age on silicic magmas across an accreted terrane-Precambrian crust boundary, Sierra Madre Occidental, Mexico. Journal of South American Earth Sciences 13, 255-273. doi: 10.1016/S08959811(00)00014-6

Barnett, V., Lewis, T. (1994): Outliers in statistical data (Third Edition). John Wiley \& Sons, Chichester, 584 p.

Bellon, H., Aguillón-Robles, A., Calmus, T., Maury, R.C., Bourgois, J., Cotten, J. (2006): La Purisima volcanic field, Baja California Sur (Mexico): Miocene to Quaternary volcanism related to subduction and opening of an asthenospheric window. Journal of Volcanology and Geothermal Research 152, 253-272. doi:10.1016/j.jvolgeores.2005.10.005

Benoit, M., Robles, A.A., Calmus, T., Maury, R.C., Bellon , H., Cotten, J., J., B., Michaud, F. (2002): Geochemical Diversity of Late Miocene Volcanism in Southern Baja California, México: Implication of
Mantle and Crustal Sources during the Opening of an Asthenospheric Window. Journal of Geology 110, 627-648. doi: 10.1086/342735

Butler, J.C., Woronow, A. (1986): Discrimination among tectonic settings using trace element abundances of basalts. Journal of Geophysical Research 91, 10289-10300. doi: 10.1029/JB091iB10p10289

Cabanis, B., Lecolle, M. (1989): Le diagramme La/10-Y/15-Nb/8: un outil pour la discrimination des séries volcaniques et la mise en évidence des processus de mélange et/ou de contamination crustale. C.R. Acad. Sci. Paris 309, 2023-2029.

Calmus, T., Aguillón-Robles, A., Maury, R.C., Bellon , H., Benoit, M., Cotten, J., Bourgois, J., Michaud, F. (2003): Spatial and temporal evolution of basalts and magnesian andesites («Bajaites») from Baja California, Mexico: the role of slab melts. Lithos 66, 77-105. doi:10.1016/S0024-4937(02)00214-1

Calmus, T., Pallares, C., Maury, R.C., Robles, A.A., Bellon, H., Benoit, M., Michaud, F. (2011): Volcanic Markers of the Post-Subduction Evolution of Baja California and Sonora, Mexico: Slab Tearing Versus Lithospheric Rupture of the Gulf of California. Pure and Applied Geophysics 168, 1303-1330. doi:10.1007/s00024-010-0204-Z

Castillo, P.R., Hawkins, J.W., Lonsdale, P.F., Hilton, D.R., Shaw, A.M. (2002): Petrology of Alarcon Rise lavas, Gulf of California: Nascent intracontinental ocean crust. Journal of Geophysical Research 107, 2222. doi:10.1029/2001JB000666

Flower, M.F.J., Pritchard, R.G., Schmincke, H.-U., Robinson, P.T. (2007): Geochemistry of Basalts: Deep Sea Drilling Project Sites 482, 483, and 485 near the Tamayo Fracture Zone, Gulf of California. Deep Sea Drilling Project 65, 559-578.

Grijalva-N., F.J., Roldán-Q., J. (1998): An Overview of the Cenozoic tectonic and magmatic evolution of Sonora, Northwestern Mexico. Revista Mexicana de Ciencias Geológicas 15, 145-156.

Housh, T.B., Aranda-Gómez, J.J., Luhr, J.F. (2010): Isla Isabel (Nayarit, México): Quaternary alkalic basalts with mantle xenoliths erupted in the mouth of the Gulf of California. Journal of Volcanology and Geothermal Research 197, 85-107. doi:10.1016/j.jvolgeores.2009.06.011

Jochum, K.P., Verma, S.P. (1996): Extreme enrichment of Sb, Tl and other trace elements in altered MORB. Chemical Geology 130, 289299. doi:10.1016/0009-2541(96)00014-9

Le Bas, M.J., Le Maitre, R.W., Streckeisen, A., Zanettin, B. (1986): A chemical classification of volcanic rocks based on the total alkali-silica diagram. Journal of Petrology 27, 745-750. doi:10.1093/petro$\operatorname{logy} / 27.3 .745$

Lopez M., M., Perez R., J., Urrutia F., J., Pal, S., Terrell, D.J. (1978): Geochemistry and petrology of some volcanic rocks dredged from the Gulf of California. Geochemical Journal 12, 127-132.

Luhr, J.F., Aranda-Gómez, J.J., Housh, T.B. (1995): San Quintín volcanic field, Baja California Norte, México: geology, petrology, and geochemistry. Journal of Geophysical Research 100, 10353-10380. doi: 10.1029/95JB00037

Mammerickx, J., Klitgord, K.D. (1982): Northern East Pacific Rise: evolution from 25 m.y. B.P. to the Present. Journal of Geophysical Research 87, 6751-6759. doi: 10.1029/JB087iB08p06751

McDowell, F.W., Keizer, R.P. (1977): Timing of mid-tertiary volcanism in the Sierra Madre Occidental between Durango City and Mazatlan, Mexico. Geological Society of America Bulletin 88, 1479-1487. doi:10.1130/0016-7606(1977)88<1479:TOMVIT>2.0.CO;2

McDowell, F.W., Roldán-Q., J., Amaya-M. R. (1997): Interrelationship of sedimentary and volcanic deposits associated with Tertiary extension in Sonora, Mexico. Geological Society of America Bulletin 109, 1349-1360. doi:10.1130/0016-7606(1997)109<1349:IOSAVD>2.3. $\mathrm{CO} ; 2$

McDowell, F.W., Roldán-Q., J., Connelly, J. N. (2001): Duration of Late Cretaceous-early Tertiary magmatism in east-central Sonora, Mexico. Geological Society of America Bulletin 113, 521-531. doi:10.1130/0016-7606(2001)113<0521:DOLCET>2.0.CO;2 
Meschede, M. (1986): A method of discriminating between different types of mid-ocean ridge basalts and continental tholeiites with the Nb-Zr-Y diagram. Chemical Geology 56, 207-218. doi:10.1016/00092541(86)90004-5

Middlemost, E.A.K. (1989): Iron oxidation ratios, norms and the classification of volcanic rocks. Chemical Geology 77, 19-26. doi:10.1016/0009-2541(89)90011-9

Morrison, M.A., Thompson, R.N. (2007): Alteration of Basalt: Deep Sea Drilling Project Legs 64 and 65. Deep Sea Drilling Project 65, 643-660.

Mullen, E.D. (1983): $\mathrm{MnO} / \mathrm{TiO}_{2} / \mathrm{P}_{2} \mathrm{O}_{5}$ : a minor element discrimination for basaltic rocks of oceanic environments and its implications for petrogenesis. Earth and Planetary Science Letters 62, 53-62. doi:10.1016/0012-821X(83)90070-5

Pallares, C., Maury, R.C., Bellon, H., Royer, J.-Y., Calmus, T., AguillónRobles, A., Cotten, J., Benoit, M., Michaud, F., Bourgois, J. (2007): Slab-tearing following ridge-trench collision: evidence from Miocene volcanism in Baja California, Mexico. Journal of Volcanology and Geothermal Research 161, 95-117. doi:10.1016/j.jvolgeores.2006.11.002

Pearce, J.A. (1975): Basalt geochemistry used to investigate past tectonic environments on Cyprus. Tectonophysics 25, 41-67. doi:10.1016/0040-1951(75)90010-4

Pearce, J.A. (1976): Statistical analysis of major element patterns in basalts. Journal of Petrology 17, 15-43. doi:10.1093/petrology/17.1.15

Pearce, J.A. (1982): Trace element characteristics of lavas from destructive plate boundaries. in Andesites. R.S. Thorpe, Ed. Chichester: John Wiley \& Sons, 528-548.

Pearce, J.A., Cann, J.R. (1973): Tectonic setting of basic volcanic rocks determined using trace element analyses. Earth and Planetary Science Letters 19, 290-300. doi: 10.1016/0012-821X(73)90129-5

Pearce, J.A., Gale, G.H. (1977): Identification of ore-deposition environment from trace-element geochemistry of associated igneous host rocks. Geological Society of London Special Publication 7, 14-24. doi:10.1144/GSL.SP.1977.007.01.03

Pearce, J.A., Norry, M.J. (1979): Petrogenetic implications of Ti, Zr, Y, and $\mathrm{Nb}$ variations in volcanic rocks. Contributions to Mineralogy and Petrology 69, 33-47.

Pearce, T.H., Gorman, B.E., Birkett, T.C. (1977): The relationship between major element chemistry and tectonic environment of basic and intermediate volcanic rocks. Earth and Planetary Science Letters 36, 121-132. doi:10.1016/0012-821X(77)90193-5

Perfit, M.R., Saunders, A.D., Fornari, D.J. (2007): Phase Chemistry, Fractional Crystallization, and Magma Mixing in Basalts from the Gulf of California, Deep Sea Drilling Project Leg 64. Deep Sea Drilling Project 64, 649-666.

Rogers, G., Saunders, A.D., Terrell, D.J., Verma, S.P., Marriner, G.F. (1985): Geochemistry of Holocene volcanic rocks associated with ridge subduction in Baja California, Mexico. Nature 315, 389-392. doi: $10.1038 / 315389 \mathrm{a} 0$

Rollinson, H.R. (1993): Using geochemical data: evaluation, presentation, interpretation. Longman Scientific Technical, Essex: 344 p.

Saunders, A.D. (2007): Geochemistry of Basalts Recovered from the Gulf of California during Leg 65 of the Deep Sea Drilling Project. Deep Sea Drilling Project 65, 591-621.

Saunders, A.D., Fornari, D.J., Joron, J.-L., Tarney, T., M., T. (2007): Geochemistry of Basic Igneous Rocks, Gulf of California, Deep Sea Drilling Project Leg 64. Deep Sea Drilling Project 64, 595-642.

Saunders, A.D., Rogers, G., Marriner, G.F., Terrell, D.J., Verma, S.P. (1987): Geochemistry of Cenozoic volcanic rocks, Baja California, Mexico: implications for the petrogenesis of post-subduction magmas. Journal of Volcanology and Geothermal Research 32, 223-245. doi:10.1016/0377-0273(87)90046-1

Shervais, J.W. (1982): Ti-V plots and the petrogenesis of modern and ophiolitic lavas. Earth and Planetary Science Letters 59, 101-118. doi:10.1016/0012-821X(82)90120-0

Sheth, H.C. (2008): Do major oxide tectonic discrimination diagrams work? Evaluating new log-ratio and discriminant-analysis-based diagrams with Indian Ocean mafic volcanics and Asian ophiolites. Terra Nova 20, 229-236. doi:10.1111/j.1365-3121.2008.00811.x

Solano, V.J., Moreno, F.A.P., Iriondo, A., Demant, A., Cochemé, J.-J. (2005): Middle Miocene peralkaline ignimbrites in the Hermosillo region (Sonora, Mexico): Geodynamic implications. Geomaterials (Petrology) 337, 1421-1430. doi:10.1016/j.crte.2005.08.007

Spencer, J.E., Normark, R. (1979): Tosco-Abreojos fault zone: A Neogene transform plate boundary within the Pacific margin of southern Baja California, Mexico. Geology 7, 554-557. doi: 10.1130/0091-7613(1979)7<554:TFZANT>2.0.CO;2

Stock, J.M., Lee, J. (1994): Do microplates in subduction zones leave a geological record? Tectonics 13, 1472-1487. doi:10.1029/94TC01808

Till, C.B., Gans, P.B., Spera, F.J., MacMillan, I., Blair, K.D. (2009): Perils of petrotectonic modeling: A review from southern Sononra, Mexico. Journal of Volcanology and Geothermal Research 186, 160 68. doi:10.1016/j.jvolgeores.2009.06.014

Vasconcelos-F., M., Verma, S.P., Rodríguez-G., J.F. (1998): Discriminación tectónica: nuevo diagrama $\mathrm{Nb}-\mathrm{Ba}$ para arcos continentales, arcos insulares, "rifts" e islas oceánicas en rocas máficas. Boletín de la Sociedad Española de Mineralogía 21, 129-146.

Vasconcelos-F., M., Verma, S.P., Vargas-B., R.C. (2001): Diagrama Ti$\mathrm{V}$ : una nueva propuesta de discriminación para magmas básicos en cinco ambientes tectónicos. Revista Mexicana de Ciencias Geológicas $18,162-174$.

Verma, S.K., Pandarinath, K., Verma, S.P. (2012): Statistical evaluation of tectonomagmatic discrimination diagrams for granitic rocks and proposal of new discriminant-function-based multi-dimensional diagrams for acid rocks. International Geology Review 54, 325-347. doi :10.1080/00206814.2010.543784

Verma, S.P. (1997): Sixteen statistical tests for outlier detection and rejection in evaluation of International Geochemical Reference Materials: example of microgabbro PM-S. Geostandards Newsletter. The Journal of Geostandards and Geoanalysis 21, 59-75. doi:10.1111/ j.1751-908X.1997.tb00532.x

Verma, S.P. (2000): Geochemistry of the subducting Cocos plate and the origin of subduction-unrelated mafic volcanism at the volcanic front of the central Mexican Volcanic Belt. in Cenozoic tectonics and volcanism of Mexico. H. Delgado-Granados, Aguirre-Díaz, G., Stock, J.M., Eds., Geological Society of America Special paper 334: 195222.

Verma, S.P. (2010): Statistical evaluation of bivariate, ternary and discriminant function tectonomagmatic discrimination diagrams. Turkish Journal of Earth Sciences 19, 185-238. doi:10.3906/yer-0901-6

Verma, S.P. (2012): Geochemometrics. Revista Mexicana de Ciencias Geológicas 29(1), 276-298.

Verma, S.P., Agrawal, S. (2011): New tectonic discrimination diagrams for basic and ultrabasic volcanic rocks through log-transformed ratios of high field strength elements and implications for petrogenetic processes. Revista Mexicana de Ciencias Geológicas 28, 24-44.

Verma, S.P., Díaz-González, L. (2012): Application of discordant outlier detection and separation system in geosciences. International Geology Review 54, 593-614. doi:10.1080/00206814.2011.569402

Verma, S.P., Rivera-Gómez, M.A. (2012): New computer program $\mathrm{TecD}$ for tectonomagmatic discrimination from discriminant function diagrams for basic and ultrabasic magmas and its application to ancient rocks. Journal of Iberian Geology 167-180, doi: 10.5209/ rev JIGE.2013.v39.n1.41757.

Verma, S.P., Quiroz-Ruiz, A. (2006a): Critical values for six Dixon tests for outliers in normal samples up to sizes 100, and applications in science and engineering. Revista Mexicana de Ciencias Geológicas 
23, 133-161.

Verma, S.P., Quiroz-Ruiz, A. (2006b): Critical values for 22 discordancy test variants for outliers in normal samples up to sizes 100, and applications in science and engineering. Revista Mexicana de Ciencias Geológicas 23, 302-319.

Verma, S.P., Quiroz-Ruiz, A. (2008): Critical values for 33 discordancy test variants for outliers in normal samples for very large sizes of 1,000 to 30,000. Revista Mexicana de Ciencias Geológicas 25, 369381.

Verma, S.P., Torres-Alvarado, I.S., Sotelo-Rodríguez, Z.T. (2002): SINCLAS: standard igneous norm and volcanic rock classification system. Computers \& Geosciences 28, 711-715. doi:10.1016/S00983004(01)00087-5

Verma, S.P., Torres-Alvarado, I.S., Velasco-Tapia, F. (2003): A revised CIPW norm. Schweizerische Mineralogische und Petrographische Mitteilungen 83, 197-216.

Verma, S.P., Guevara, M., Agrawal, S. (2006): Discriminating four tectonic settings: five new geochemical diagrams for basic and ultrabasic volcanic rocks based on log-ratio transformation of major-element data. Journal of Earth System Science 115, 485-528.

Verma, S.P., Quiroz-Ruiz, A., Díaz-González, L. (2008): Critical values for 33 discordancy test variants for outliers in normal samples up to sizes 1000, and applications in quality control in Earth Sciences. Revista Mexicana de Ciencias Geológicas 25, 82-96.

Verma, S.P., Rodríguez-Ríos, R., González-Ramírez, R. (2010): Statistical evaluation of classification diagrams for altered igneous rocks. Turkish Journal of Earth Sciences 19, 239-265. doi:10.3906/yer0902-9
Verma, S.P., Verma, S.K. (2013): First fifteen probability-based multidimensional tectonic discrimination diagrams for intermediate magmas and their robustness against post-emplacement compositional changes and petrogenetic processes. Turkish Journal of Earth Sciences (in press) doi:10.3906/yer-1204-6.

Verma, S.P., Verma, S.K., Pandarinath, K., Rivera-Gómez, M.A. (2011): Evaluation of recent tectonomagmatic discrimnation diagrams and their application to the origin of basic magmas in Southern Mexico and Central America. Pure and Applied Geophysics 168, 1501-1525. doi:10.1007/s00024-010-0173-2

Vermeesch, P. (2006): Tectonic discrimination of basalts with classification trees. Geochimica et Cosmochimica Acta 70, 1839-1848. doi:10.1016/j.gca.2005.12.016

Vermeesch, P. (2007): Tectonic discrimination diagrams revisited. Geochemistry Geophysics Geosystems 7, Q06017. doi:10.1029/2005GC001092

Vidal-Solano, J.R., Demant, A., Moreno, F.A.P., Lapierre, H., OrtegaRivera, M.A., Lee, J.K.W. (2008): Insights into the tectonomagmatic evolution of NW Mexico: Geochronology and geochemistry of the Miocene volcanic rocks from the Pinacate area, Sonora. Geological Society of America Bulletin 120, 691-708. doi:10.1130/B26053.1

Wood, D.A. (1980): The application of a Th-Hf-Ta diagram to problems of tectonomagmatic classification and to establishing the nature of crustal contamination of basaltic lavas of the British Tertiary volcanic province. Earth and Planetary Science Letters 50, 11-30. doi:10.1016/0012-821X(80)90116-8

Zolotarev, B.P., Margolin, E.M. (2007): Geochemistry and rare-earth element abundances of basalts from Sites 482, 483, and 485 in the Gulf of California. Deep Sea Drilling Project 65, 579-590. 